\title{
DIGITALIZATION OF EDUCATION \\ AS A CONDITION FOR TEACHER PROFESSIONAL DEVELOPMENT
}

\author{
Victoria Tarasova \\ Postgraduate Student, Bogdan Khmelnytsky Melitopol State Pedagogical University, Ukraine \\ e-mail: marsetka11@gmail.com,orcid.org/0000-0003-1250-2027
}

\section{Summary}

The article deals with the issue of distance learning implementation during the Covid-19 pandemic and the readiness of teachers for professional development by means of information and communication technologies. Significant problems that arose during the organization of distance learning in educational institutions during the pandemic crisis are noted. The rapid development of digital and information technologies has led to new prospects for personal development in a networked society. Theoretical provisions on the essence of the notions "information competence", "digitalization of education", "distance learning" are considered. The content of distance learning platforms such like Edera, Prometheus, EdX, Coursera for the development of teachers' professional competence, including information and communication competence in the intercourse period is analyzed.The possibility of introducing new methods of pedagogical support of tutoring, coaching and mentoring during the organization and implementation of competency-based learning is considered. The article can be useful for specialists of general secondary education during the organization of distance learning and in the development of individual plans for professional development of pedagogical staff.

Keywords: information competence, distance learning, coach, mentor, tutor, non-formal education.

\section{DOI: https://doi.org/10.23856/3830}

\section{Introduction}

During 2019-2020, humanity faced a surprisingly global problem on a worldwide scale, the Covid-19 coronavirus pandemic. The education systems of different countries, including Ukraine, found themselves in new conditions that required rapid action and reorganization of the educational process, which led to a thorough rethinking and search for modern approaches to the organization of the educational process by means of distance learning. Despite the fact that the introduction of digital technologies in the educational process over the past two decades has been fairly rapid, the enough impact on the professional level of proficiency and the quality of teacher training has not been achieved. The pace of digital technology is far surpassing any other technology of previous generations. Scientists testify that due to the appearance of new information, the aging of professional knowledge, and hence the decline in employee competence, is annually updated about $10 \%$ of theoretical and $25 \%$ of professional knowledge.Changing the paradigm of the educational process from subject to person-centeredrequires the search for modern relevant forms of pedagogical process, there is a need to develop and implement new approaches to organizing the educational process in educational institutions, mastering modern pedagogical technologies and methods of students' pedagogical support in the educational process, which are able to implement the tasks of pedagogy by means of digital education. One of the main challenges of the digital transformation in education has been the need for mass training and retraining of teachers. Rapid transition from the traditional (full-time) system 
to the remote system training intensified the work of all members of the teaching staff to quickly master the technical means of training.

The aim of the article is to analyze the readiness of teachers to organize and implement distance learning during a pandemic crisis, to identify opportunities for teachers' professional development by means of distance learning in the intercourse period. To achieve the aim of the study, such theoretical methods were used: comparative analysis of pedagogical literature, generalization of scientific and theoretical data to reveal the problems of distance learning and teachers' training.

The rapid development of information technology makes information and digital competence key for everyone, the ability to work with digital technologies is a priority requirement in today's labor market. During the Covid-19 pandemic, the education system faced certain challenges that sometimes made it impossible to organize distance learning in educational institutions, including the lack of an effective distance learning system at the time of quarantine, the lack of distance learning programs and professionals who ready to create their own educational content, insufficient methodological preparation of teachers for distance learning, not all students have gadgets and access to the Internet, which causes the emergence of "digital inequality".

Informatization of the educational process should ensure the implementation of software and pedagogical guidelines, improve forms and methods of organizing the educational process aimed at intensifying the educational process. The works of N. Bibik, L. Bilousova, M. Zhaldak, E. Markova, N. Olefirenko, V. Osadchyi, O. Savchenko, O. Spivakovskyi, O. Shyman and others are devoted to the problems of informatization in education. The experience of using information and communication technologies in education practice is reflected in scientific researches of Yu. Horvyts, O. Kryvliuk, M. Levshyn, N. Morse, Yu. Pervin, O. Rybalko, N. Sarazhynska, S. Khomych, L. Khoruzha, general and technical issues of using the Internet technologies in education were studied by V. Bykov, A. Vahramenko, Yu. Zhuk, K. Kolin and others.

Currently, in quarantine, the need for the implementation of the educational process by means of distance learning and effective methods of pedagogical support of the educational process becomes very relevant, so the development of teachers' information competence acquires a new vector of development andmodern approaches to its formation.

The term "distance learning" came into use in the West in the mid-1970s, with the opening of a new type of institution, open universities. The first distance learning program was successfully launched in Western Europe in 1988 (Vasiuk, 2011). Distance learning is an open education system which that involves active communication between teacher and student with the help of modern technologies and multimedia tools. This form of education provides certain advantages, e.g. free choice of place, time and pace of learning. The Order of the Ministry of Education and Science of Ukraine dated 25.04.2013 № 466 "On approval of the regulations on distance learning" states that distance learning is an individual process of acquiring knowledge, skills, abilities and ways of human cognitive activity, which occurs mainly through indirect interaction of remote from each other participants in the learning process in a specialized environment that operates on the basis of modern psychological, pedagogical, information and communication technologies (Kravchenko, 2020). The organization of distance learning in an educational institution involves the creation of an appropriate educational environment and conditions, namely the availability of computer equipment (individual PC, laptops, tablets, smartphones etc.), high-speed Internet access, licensed training programs etc. When organizing distance learning, the teacher's first task is to take into account the age and 
psychological characteristics of the relevant category of pupils (primary, general, senior), who will master educational material, select the material so that it implement the State Standard and Educational Program, its size, content, tasks, consider feedback from pupils. Develop a lesson to make it as accessible as possible, interesting, visual, motivating and stimulating to learn and expand knowledge (Akhaian, 2007). To do this, the teacher should adjust the calendar-thematic planning, optimize the educational material and review the expected results, taking into account the conditions of distance learning. Themes, that cannot be mastered by pupils themselves, should be postponed to a later date (if possible). When preparing for online lessons, the time for presentation the educational material should be taken into account, it should be less than 35-40 minutes of a traditional lesson, also you should not start distance learning on a new theme. For better communication with pupils and parents' understanding of the education goals, it is necessary to develop an online schedule (lesson model) taking into account the topic, expected learning outcomes and selected tasks, types of work that will ensure the achievement of learning outcomes. The issue of feedback on meeting the educational process, educational needs, psychological comfort, compliance with the content and mode of learning, creating opportunities for the development of creative potential of pupils, etc. is extremely important. Feedback is the basis for the interaction of all participants in the educational process, it serves as a basis for planning and improving the educational process by means of distance learning, allows teachers to respond quickly to difficulties in mastering the material. The quality of distance learning depends on many factors, e.g. selection of educational material, skill and level of information technologies mastery by the teacher, the content of the lesson, the provision of technical means etc. When organizing distance learning, the teacher should form the educational content so that in the educational process pupils develop the need for independent knowledge, the ability to operate with information from various sources, to create conditions for active learning using modern pedagogical technologies which stimulate disclosure of pupils' internal potential and the development of their individual educational trajectory.

When the structured effect of time and place, which is generated by schools, decreases and online learning begin to play a dominant role, the role of teachers does not decrease, but rather increases. The teacher keeps an important place in the direction and coordination of pupils' learning through direct teaching or through methodical assistance in pupils' support, including distance learning, in synchronous and asynchronous modes. Synchronous mode (online mode) allows the teacher to cooperate with pupils in real time, the advantage is the instant involvement of pupils in the educational process, as all participants are in the web environment at the same time. Asynchronous mode (offline mode) provides the implementation of the educational process in a convenient time mode for pupils with audio-, video lessons, discussion board, presentations etc. When choosing a mode of study, the teacher should combine synchronous and asynchronous modes, mixed learning will form in pupils a responsible attitude to self-mastery of subjects, but accompanied and adjusted by the teacher. Modern trends in the development of innovative society due to the rapid development of information technology, prepare a challenge for teachers who should constantly develop, deepen their professional knowledge and increase professional competence, including the mastery of information and communication technologies in education (Sokolova, 2013).

One of the important issues is the training and retraining of teachers, who have problems with mastering and applying computer technologies, creating educational programs, modern techniques and tools that facilitate visualization during distance learning: interactive interface, e-textbooks, interactive presentations, e-notes, video lessons, etc. Teacher information 
competence, as noted by A. Akhaian and O. Kyzyk, is closely related to the ability to use information technology, gadgets and apply information and communication methods. In a broad sense - with the ability to rethink information, solve information retrieval problems using various information retrieval systems, i.e. to carry out information activities using both traditional and new technologies (Akhaian, 2007).

The rapid introduction of information technologies in everyday life, and in the educational system in particular, makes digital competence key for every modern person and today digitalization is a major factor in the development of the world labor market. The ability to work with digital technologies has become the life norm. It is impossible to imagine the educational process without information technologies, educational programs require the use of modern educational technological tools that contribute to the visualization of learning: interactive interface, multimedia content, online courses, online exams, tests, electronic (digital) textbooks, interactive presentations, electronic notes etc. The most popular educational platforms and services for e-learning in Ukraine are "iLEARN", "MOODLE", "MY CLASS", "PADLET", "LEARNINGAPPS", "CLASSTIME”, "EQUITY MAPS”, "GOOGLE CLASSROOM", "GOOGLE SITES”, GOOGLE FORMS, Zoom, Viber, Telegram, Skype, Meet.google.com, etc. were used to create effective interactive teacher-pupil-parent feedback during distance learning.

Modern education requires from the teacher new approaches to the support and development of personality. The teacher's pedagogical activity acquires new functions: facilitation, tutoring and coaching. In the system of education, the approach of which is focused on the pupil, the most popular are the methods of "coaching", "tutoring" and "facilitation". This practice originated in the early 70's in Western Europe, is a modern tool for personal and professional development. Scientists A. Andriiev and N. Dolyna believe that the method of coaching arose on the border of psychology, management, philosophy and logic, which makes coaching a tool that reveals the inner potential of man. The scientists' works deals with the innovation and advantages of this technique in the work on the formation of personality and his or her development. The implementation of this approach allows an individual not to be a pupil, but to be a partner in the educational process. In the Concept "New Ukrainian School" considerable attention is paid to the implementation of educational activities in educational institutions on a partnership basis. The pedagogy of partnership is based on the principles of humanism and creative approach to personal development, the transition to a qualitatively new level of building relationships between all participants in the educational process. Coaching technology is inherent in higher education, postgraduate education, etc., but we see that the coach's activities implement the functions inherent in the modern teacher, which include: mentoring, communication, coordination, partnership in the educational process, especially during distance learning. A modern teacher can act as a mentor (from the Latin mentor intention, purpose, spirit) - teacher, mentor, leader, consultant (Vylegzhanina, 2015). "Mentoring" in the educational process is implemented as a didactic, personal long-term relationship between a competent mentor and the applicant on the basis of professional, academic and personal development (Byrko, 2018). To implement group communication activities, the teacher can act as a facilitator (from Latin facilis - easy, convenient). The facilitator is a person who provides group communication during the meeting, provides the rules of group work between participants of the process. Taking into account the international practice, it can be argued that these techniques (mentoring, coaching, tutoring) promote the development of personality and academic achievements of pupils and can be applied at all levels of formal and non-formal education.

Digital technologies provide lots of possibilities to master the educational material at a convenient time, allow to design an individual educational trajectory and give the opportunity 
of lifelong learning. Distance learning requires a teacher to widely use information, communication and digital technologies, and therefore have information and digital competence. Information and digital competence involves the teacher's ability to navigate in the information and digital space, to find and organize information in accordance with the needs and requirements of modern society. One of the professional competencies of a modern teacher is information and digital competence. Ability to navigate in the information space, search and critically evaluate information, be able to operate it in professional activities, through the use of personal computers, office equipment, e-textbooks, teaching and methodical manuals, instructions, recommendations in electronic forms, visual aids and pedagogical software means (Sokolova, 2013). That is why in order to correct knowledge and skills in the field of modern information and communication technologies in education, the issues of systematic mastering and improvement of information and communication technologies of teachers in the intercourse period are acquired.

S. Kravchenko notes that digitalization in education is the creation of digital educational content, it is not only a tool but also a living environment that reveals new opportunities. For example, learning at a convenient time, lifelong learning, the ability to develop their own educational trajectory through the Internet, etc. (Kravchenko, 2020).

L. Yemets claimes that the informatization of education is one of the main directions of the informatization process, dictated by the needs of modern society, in which the main driver of progress is individual development (Yemets et al., 2013).

Distance educational platforms have been created for the professional development of teachers on the Internet: Prometheus is the first and largest free education project for everyone in Ukraine, created in 2014 by Ivan Prymachenko and Oleksii Molchanovskyi for mass open online courses. Among its partners are the best universities in the country: Kyiv-Mohyla Academy, Kyiv National University named after Taras Shevchenko, Kyiv Polytechnic Institute, Ukrainian Catholic University and Lviv IT School (LITS). Coursera is a project that changed the perception of online learning, founded in 2012 by Stanford University computer science professors Andrew Ng and Daphne Koller. According to statistics in 2016, Coursera had 1,563 training courses prepared by 140 universities from 28 countries. EdEra is a Ukrainian project, an online education studio, a platform for mass open online courses. The peculiarity of EdEra is that the platform offers a wide range of courses that are focused on teachers: on teaching in primary school, non-discriminatory approaches in education, working with children with special educational needs etc. In the EdEra blog, the platform team provides tips on how to effectively summarize, learn, and memorize materials. EdEra partners include the Ministry of Education and Science of Ukraine, Osvitoria, VoxUkraine, Intel, Studway and many others. For pupils, EdEra offers a platform to prepare for external independent assessment. $E d X$ is an open interactive course platform founded by Harvard University's Massachusetts Institute of Technology. On this platform you can take training programs from the world's best universities online. EdX courses are divided by topics, level of difficulty and languages. In the course menu, all these filters can be configured so that the system offers you exactly the ones that suit you the best. EdX, like Coursera, has free and paid courses. It all depends on the program and which higher education institution prepared it: there may be paid certificates or study materials. $\mathrm{EdX}$ is praised for supporting tutors who can prompt and correct students' mistakes, but if you are not willing to pay for it, you can sign up for the curriculum in "auditlearner" mode. Educational platform operates a loyal system of financial assistance for those who really want to study on the platform, but do not have money to pay for it. The assistance can be up to $90 \%$ of the cost. Developing video lessons, Salmon Khan launched a full-fledged educational platform 
"Khan Academy". The educational field of mathematics and computer science is widely represented on the platform. The open platform does not require registration and has three sections "For pupils", "For teachers", "For parents". The peculiarity is the lack of tests, tasks to perform, but it should be noted that there are no certificates too. According to the plan of the the platform founder, pupils, teachers, parents should decide at what pace to study and how deeply they want to study a particular subject. Hence, we can see that information and communication competence is defined as one of the basic competencies all over the world.

\section{Conclusions}

The pandemic has accelerated the use of electronic services and the acquisition of distance technologies by teachers and education applicants. It led to the rapid development of mastering new methods and technologies of accompanying pupils during distance learning. But in the current challenges caused by the COVID-19 pandemic, global cataclysms, military conflicts, environmental and economic disruptions that threaten the right to unimpeded and accessible education of children and youth in Ukraine and around the world, the education system needs a thorough rethinking and finding new approaches to learning and personal development. The demand for distance learning is growing, quarantine has shown that not all teachers are ready to work remotely, not all are able to rethink and restructure the educational process. The education system of different levels faces new challenges, including: the official launch of the permanent National Educational Electronic Platform, the development of educational materials, software for distance learning; means of monitoring pupils' academic achievements, providing correction of the educational program for revision and assimilation of educational material; methodological support, training and retraining of teachers in digital technologies and providing educational institutions with technical equipment for remote learning, connection and access to the Internet, quality of the Internet, increasing attention to families in difficult circumstances to reduce educational inequality, etc. Educational processes are in a state of transformation, the world around us is becoming more mobile under the influence of many factors, thus education should become more flexible and individualized.

\section{References}

Akhaian, A. (2007). Orhanizatsiia dystantsiinoho navchannia v shkoli [Organization of distance learning at school]. Elektronnyj nauchno-pedagogicheskij zhurnal. Retrieved from https://mon.gov.ua/storage/app/media/zagalna\%20serednya/metodichni\%20recomendazii/2020/metodichni\%20recomendazii-dustanciyna\%20osvita-. [in Ukrainian] Byrko, N. (2018). Teoretyko-metodolohichni zasady pedahohichnoi tvorchosti, maisternosti, profesionalizmu [Theoretical and methodological principles of pedagogical creativity, craftsmanship, professionalism]. Retrieved from http://enpuir.npu.edu.ua/bitstream/123456789/21721/1/ Byrko.pdf. [in Ukrainian]

Declaration of Principles. Building the Information Society: a global challenge in the new Millennium (n.d.). Retrieved from http://www.itu.int/wsis/docs/geneva/official/dop.html.

Fisun, O. (2010). Pedahohichna fasylitatsiia yak bahatoznachnyi fenomen. [Pedagogical facilitation as a multifaceted phenomenon]. Zasoby navchalnoi ta naukovo-doslidnoi roboty: zb. nauk. prats KHPU im. H. S. Skovorody, 34, 133-139. [in Ukranian]

Hordiienko, T. (n.d.). Retrieved from https://ms.detector.media/onlainmedia/post/21728/ 2018-09-01-nikoli-ne-pizno-5-platform-dlya-samoosviti. 
Information and Communication Technology in Education: A Curriculum for Schools and Programme of Teacher Development (2002). UNESCO. Retrieved from http://unesdoc.unesco.org/ images/0012/001295/129538e.pdf.

Kontseptsiia "Nova ukrainska shkola" [The Concept of the "New UkrainianSchool”] (2017). Retrieved from https://mon.gov.ua/storage/app/media/zagalna\%20serednya/nova-ukrainskashkola-compressed.pdf.

Kravchenko, S. (2020). Tsyfrovizatsiia yak tendentsiia rozvytku shkilnoi osvity u SShA [Digitization as a trend in the development of school education in the United States]. Retrieved from http://lib.iitta.gov.ua/id/eprint/720564 [in Ukrainian]

Lebedeva, I. V., Aksyonov, S. I. (2014). Uchitel ili kouch? Sovremennye problemy nauki [Teacher or coach? Modern problems of science]. Retrieved from science-education.ru.

Osvita protiahom zhyttia: svitovyi dosvid i ukrainska praktyka. Analitychna zapyska [Lifelong learning: world experience and Ukrainian practice. Analytical note]. (n.d.). Natsionalnyi instytut stratehichnykh doslidzhen. Retrieved from http://www.niss.gov.ua/articles/252.

Polozhennia pro dystantsiine navchannia. Nakaz Ministerstva osvity $i$ nauky Ukrainy vid 25.04.2013 № 466 [Provision on distance learning. Order of the Ministry of Education and Science of Ukraine dated 25.04.2013 № 466] (2013). Retrieved from https://zakon.rada.gov.ua/ laws/show/z0703-13\#Text.

Profesiinyi standart za profesiiamy "Vchytel pochatkovykh klasiv zakladu zahalnoi serednoi osvity" ta "Vchytel zakladu zahalnoi serednoi osvity" [Professional standard for the professions "Primary school teacher of General secondary education institutions" and "Teacher of General secondary education institutions"]. (n.d.). Retrieved fromhttps://mon.gov.ua/ua/news/ mon-rozrobilo-novij-profesijnij-standart vchitelya-dokument-na-gromadskomu-obgovorenni.

Sokolova, E. (2013). Analiz terminologicheskogo ryada "kouch”, “mentor”, "tyutor”, "fasilitator", v kontekste nepreryvnogo obrazovaniya [The analysis of terminological row "coach, mentor, tutor, facilitator" within the frame of lifelong learning]. Nepreryvnoe obrazovanie: XXI vek, (4), 1-11. [in Russian]

Vasiuk, O., Skumin, T. (2011). Teoretyko-metodychni aspekty orhanizatsii dystantsiinoi osvity [Theoretical and methodical aspects of distance learning]. Visnyk Knyzhkovoi palaty, 2, 1-3. [in Ukrainian]

Vylegzhanina, A. (2015). Chto takoe kouching? Tehnologiya raskrytiya potenciala cheloveka [What is coaching? Technology for unlocking human potential]. Retrieved from https://elib.utmn.ru/jspui/bitstream/ru-tsu/2091/1/679.pdf.

Woollard, J. M. (2012). The role of ICT in Western Australian Education: Living and Working in a Digital World. Perth: Parliament of Western Australia. [in English]

Yemets, Ye., Kozyr, O. O., Karnaukhova, H. V. (2013). Vykorystannia informatsiinykh tekhnolohii u protsesi formuvannia profesiinoi kompetentnosti maibutnikh kibernetykiv [The use of information technology in the process of forming the professional competence of future cyberneticists]. Retrieved from dspace.uccu.org.ua. 